\title{
PERBEDAAN INDEKS PLAK PADA PEMERIKSAAN DENGAN BAHAN DISCLOSING SOLUTION DAN BIJI KESUMBA (BIXA ORELLANA)
}

\section{Differences Of Plaq Index In Examination With Disclosing Solution Material And Kesumba Seeds (Bixa Orellana)}

\author{
Erwin $^{1 *}$ \\ Asmawati $^{2}$ \\ Suhikma Sofyan ${ }^{2}$ \\ *'Poltekkes Kemenkes Jakarta I, \\ Jakarta Selatan, DKI Jakarta \\ Indonesia \\ 2 Politeknik Bina Husada \\ Kendari, Kendari, Sulawesi \\ Tenggara, Indonesia \\ *email Korespondensi: \\ Erwin7tgm@gmail.com
}

\begin{abstract}
Abstrak
Praktisi kesehatan gigi perlu mempertimbangkan pemanfaatan bahan alternatif untuk pemeriksaan indeks plak yang berasal dari bahan alami sebagai pengganti bahan disclosing karena terkendala bahan tersebut tidak selalu tersedia disamping harganya yang mahal. salah satu contoh bahan alami tersebut adalah tanaman biji kesumba. Tujuan penelitian ini untuk mengetahui perbedaan indeks plak pada pemeriksaan dengan disclosing solution dan bahan kesumba. Jenis penelitian ini ada quasy eksperiment. Penelitian ini menggunakan sampel berjumlah 47 orang murid SDN Lawulo yang berusia 9- 12 tahun, pengumpulan data dilakukan dengan pemeriksaan indeks plak PHP. Hasil penelitian menunjukkan rata-rata skor indeks plak pada pemeriksaan dengan Disclosing solution sebesar 3,08, dan rata-rata skor indeks plak pada pemeriksaan dengan kesumba sebesar 2.17 dengan selisih 0,9l. Hasil uji statistik diperoleh nilai $\rho$-value : $0,000<\alpha(0,05)$ sehingga, dapat disimpulkan terdapat perbedaan indeks plak pada pemeriksaan dengan Disclosing solution dan pemeriksaan dengan kesumba.
\end{abstract}

\begin{abstract}
Dental health practitioners need to consider the use of alternative materials for the examination of plaque indexes derived from natural ingredients as a substitute for disclosing materials because they are not always available despite the high price. one example of this natural ingredient is the kesumba seed plant. The purpose of this study was to determine the differences in plaque index on examination by disclosing solution and kesumba material. This type of research is quasi-experiment. This study used a sample of 47 students from Lawulo Elementary School-aged 9-12 years, data collection was done by checking the PHP plaque index. The results showed that the average plaque index score on examination with a disclosing solution was 3.08 , and the average plaque index score on examination with the examination was 2.17 with a difference of 0.91 . Statistical test results obtained $\rho$-value: $0,000<\alpha(0.05)$ so that, it can be concluded there are differences in the plaque index on examination with Disclosing solution and examination with kesumba.
\end{abstract}

\section{Keywords:}

Plaque Index

Disclosing Solution

Kesumba (c) yearThe Authors. Published by Institute for Research and Community Services Universitas Muhammadiyah Palangkaraya. This is Open Access article under the CC-BY-SA License (http://creativecommons.org/licenses/by-sa/4.0/). DOI: https://doi.org//0.33084/jsm.vxix.xxx.

\section{PENDAHULUAN}

Rongga mulut adalah pintu pertama dalam sistem pencernaan makanan manusia, ketidakmampuan gigi dan organ rongga mulut bekerja dengan sesuai fungsinya maka akan berpotensi membuat organ lanjutan dalam sistem pencernaan bekerja terlalu berat bahkan dapat menjadi rusak sehingga akan mengganggu kesehatan tubuh secara umum.

Berdasarkan hasil Riset Kesehatan Dasar (Riskesdas) Nasional tahun 20I3, 25,9\% masyarakat Indonesia mempunyai masalah gigi dan mulut dalam waktu I tahun terakhir. Diantara mereka terdapat 3I,I\% yang menerima perawatan dan pengobatan dari tenaga medis (perawat gigi, dokter gigi atau dokter gigi spesialis), sedangkan 68,9\% lainnya tidak dilakukan perawatan (Kemkes RI, 20I3).

Penyebab utama munculnya berbagai penyakit dalam rongga mulut manusia adalah kebersihan gigi dan mulut (oral hygiene) yang tidak terjaga. Kebersihan gigi dan mulut adalah keadaan terbebasnya gigi dan mulut dari 
deposit kotoran yang didalamnya mengandung (atau berpotensi menjadi tempat tumbuh) miroorganisme pathogen. Salah satu deposit kotoran yang ada pada permukaan gigi adalah Plak.

Plak merupakan akumulasi deposit lunak yang membentuk biofilm, menempel pada permukaan gigi atau permukaan keras lainnya pada rongga mulut. Plak mengandung bakteri, melekat pada permukaan gigi dan selalu terbentuk di dalam mulut dan bila bercampur dengan gula yang ada di dalam makanan yang kita makan, akan membentuk asam. Penumpukan plak yang semakin memburuk akan memicu berbagai masalah rongga mulut seperti karies gigi, karang gigi, bau mulut, peradangan gusi, dan infeksi rongga mulut berat lainnya seperti abses, kista, hingga kanker rongga mulut, Plak gigi tidak dapat dilihat secara langsung, dengan demikian dibutuhkan suatu senyawa yang digunakan untuk membantu melihat plak gigi (Newman et al, 2002).

Tingkat pertumbuhan plak pada gigi dapat diukur dengan instrument indeks PHP (personal Hygiene performance), indeks PHP adalah mekanisme pemeriksaan pertumbuhan deposit plak pada pemukaan gigi dengan mengamati pewarnaan yang tampak sebagai akibat diserapnya bahan pewarna yang dipakai oleh plak tersebut. Dalam Ilmu Kedokteran Gigi prosedur pemeriksaan plak idealnya menggunanakan bahan pewarna disclosing solution atau disclosing solution.

Permasalahan yang timbul selama ini adalah sulitnya mendapatkan bahan disclosing solution produksi pabrikan bahan kedokteran gigi dijual dipasaran. Selain harganya yang cukup mahal bahan ini juga sangat jarang tersedia stoknya dan hanya dijual khusus oleh distributor/toko bahan kedokteran gigi yang sangat langka ada di setiap daerah, Oleh karena itu perlu dicarikan alternatif bahan alami pengganti untuk prosedur pemeriksaan plak tapi tetap menghasilkan nilai yang akurat menggambarkan pertumbuhan plak pada permukaan gigi tersebut. Salah satunya adalah dengan menggunakan bahan alami yaitu serbuk tanaman Kesumba. Bahan ini sangat umum digunakan oleh masyarakat sebagai pewarna alami makanan, Penelitian terdahulu yang menggunakan bahan alami tanaman sebagai bahan untuk memeriksa plak dilakukan oleh Fatmasari et al (2014) hasil penelitian menunjukkan ada perbedaan indeks plak setelah pengolesan sari buah bit (Beta Vulgaris) sebagai disclosing Solution.

Alternatif bahan alami kesumba tersebut sangat penting diketahui kemampuan akurasi pengukurannya agar dapat memberikan keyakinan pada praktisi kesehatan gigi untuk memakainya jika tidak tersedia bahan disclosing. Tujuan penelitian ini untuk mengetahui perbedaan indeks plak pada pemeriksaan dengan disclosing solution dan bahan kesumba.

\section{METODOLOGI}

Alat dan bahan

Lembat Observasi indeks PHP, Kaca mulut (mirror), sonde, excavator, pinset, gelas, nierbecken, masker, handscoen, sikat gigi, pasta, dan alat tulis menulis. disclosing solution, Kesumba (Bixa orellana), cotton pellet, cotton roll, alkohol 70\%, air, kapas, biskuit dan air mineral.

Metode Pelakasanaan.

Jenis penelitian ini ada quasy eksperiment. Penelitian ini menggunakan sampel berjumlah 47 orang murid SDN Lawulo, Kabupaten Konawe, Sulawesi Tenggara yang berusia 9-12 tahun. Langkah penelitian yang dilakukan yaitu setelah dilakukan pengkondisian keadaan kriteria plak awal yang sama pada setiap sampel, maka setiap sampel diberikan intervensi berupa pemeriksaan indeks plak PHP dengan menggunakan bahan disclosing solution pada percobaan pertama, kemudian pemeriksaan indeks plak dengan menggunakan bahan kesumba pada percobaan kedua

\section{HASIL DAN PEMBAHASAN}

HASIL PENELITIAN 
Penelitian ini telah dilaksanakan pada bulan April-Mei 2019 di SDN I Lawulo, Kabupaten Konawe, Provinsi Sulawesi Tenggara. diperoleh hasil penelitian sebagai berikut :

Tabel I. Distribusi Kriteria Indeks Plak Setelah Pemeriksaan dengan disclosing solution

\begin{tabular}{ccc}
\hline $\begin{array}{c}\text { Kriteria Indeks } \\
\text { Plak }\end{array}$ & $\mathrm{N}$ & $\%$ \\
\hline Baik & 2 & 4,3 \\
\hline Sedang & 14 & 29,7 \\
\hline Buruk & $3 \mathrm{I}$ & 65,9 \\
\hline Total & 47 & 100 \\
\hline
\end{tabular}

Berdasarkan tabel I diketahui setelah pemeriksaan plak dengan bahan disclosing solution diperoleh hasil tertinggi indeks plak sampel secara umum pada kriteria buruk yaitu sebesar 31 orang $(65,9 \%)$.

Tabel II. Distribusi Kriteria Indeks Plak Setelah Pemeriksaan dengan Kesumba

\begin{tabular}{ccc}
\hline $\begin{array}{c}\text { Kriteria Indeks } \\
\text { Plak }\end{array}$ & $\mathrm{N}$ & $\%$ \\
\hline Baik & 6 & 12,7 \\
\hline Sedang & 35 & 74,5 \\
\hline Buruk & 6 & 12,7 \\
\hline Total & 47 & 100 \\
\hline
\end{tabular}

Berdasarkan tabel II diketahui setelah pemeriksaan plak dengan bahan kesumba diperoleh hasil tertinggi ndeks plak sampel secara umum pada kriteria sedang yaitu sebesar 35 orang (74,5\%).

Tabel III. Uji Normalitas Data Shapiro Wilk

\begin{tabular}{lc}
\hline \multicolumn{1}{c}{ Data Variabel } & $\rho$-value \\
\hline $\begin{array}{l}\text { Pemeriksaan Indeks plak dengan } \\
\text { disclosing solution }\end{array}$ & 0,000 \\
\hline $\begin{array}{l}\text { Pemeriksaan Indeks plak dengan } \\
\text { kesumba }\end{array}$ & 0,001 \\
\hline
\end{tabular}

Tabel III Menunjukkan bahwa hasil uji normalitas data dengan Shapiro wilk menunjukkan 2 data variabel tidak berdistribusi normal $\rho$-value $<\alpha(0,05)$, sehingga analisis dilakukan dengan uji non parametric menggunakan Mann Whitney

Tabel IV. Hasil uji statistik perbedaan indeks plak pemeriksaan dengan disclosing solution dan pemeriksaan dengan kesumba

\begin{tabular}{lllll}
\hline \multicolumn{1}{c}{ Variabel } & Mean & selisih & $\begin{array}{l}\rho \text { - } \\
\text { value }\end{array}$ \\
\hline $\begin{array}{lllll}\text { Rata- } \\
\text { rata }\end{array}$ & $\begin{array}{l}\text { Pemeriksaan } \\
\text { disclosing }\end{array}$ & 3,08 & & \\
$\begin{array}{l}\text { Skkor } \\
\text { Indeks } \\
\text { plak }\end{array}$ & $\begin{array}{l}\text { solution } \\
\text { Pemeriksaan }\end{array}$ & 2,17 & & 0,91 \\
\hline
\end{tabular}

Tabel IV menunjukkan rata-rata skor indeks plak pada pemeriksaan dengan disclosing solution sebesar 3,08, dan rata-rata skor indeks plak pada pemeriksaan dengan kesumba sebesar 2.17 dengan selisih 0,9l. Hasil uji statistik diperoleh nilai $\rho$-value : $0,000<\alpha(0,05)$ sehingga, dapat disimpulkan terdapat perbedaan indeks plak pada pemeriksaan dengan disclosing solution dan pemeriksaan dengan kesumba.

\section{PEMBAHASAN}

Hasil penelitian pada tabel I diketahui setelah pemeriksaan plak dengan bahan Disclosing solution diperoleh hasil tertinggi indeks plak sampel secara umum pada kriteria buruk yaitu sebesar 31 orang (65,9\%). Hasil penelitian ini sejalan dengan penelitian Oktaviani \& Haryani (20I5) yang mendapatkan peringkat tertinggi skor plak kriteria buruk sebanyak 8 responden $(26,7 \%)$ dari 15 siswa yang diperiksa dengan disclosing solution di SDN Kradenan 3 Magelang.

Gambaran hasil penelitian tersebut menunjukkan kelompok siswa sekolah dasar adalah kelompok yang sangat beresiko ditemukan persoalan pemeliharaan kesehatan gigi dan mulut, hal tersebut karena perilaku dan tanggung jawab mandiri secara penuh untuk peduli terhadap kesehatan gigi masih sangat rendah. Menurut Amalia (dalam Fatimatuzzahro et al, 2016) Kesadaran masyarakat Indonesia khususnya anak-anak sekolah dasar, tingkat pengetahuan kesehatan gigi dan mulut masih sangat rendah dan belum menjadi prioritas.

Hasil penelitian pada tabel II diketahui setelah pemeriksaan plak dengan bahan kesumba diperoleh hasil tertinggi indeks plak sampel secara umum pada kriteria sedang yaitu sebesar 35 orang (74,5\%). Hasil ini menunjukkan kemampuan bahan kesumba untuk memberikan pewarnaan pada plak gigi, Kesumba (Bixa 
Orellana) merupakan bahan pewarna alami untuk yang umum ditemukan pada masyarakat. Suparmi, et al, (20II) menyatakan tanaman biji kesumba merupakan pewarna alami untuk makanan, yang mengandung bixin. zat Bixin tersebut akan memberikan warna kuning, orange, jingga sampai merah pada makanan.

Kemampuan penyerapan warna kesumba tersebut karena komposisi plak yang mengandung bahan organik. Bahan organic merupakan zat utama yang juga ditemukan pada makanan sehari-hari. Menurut Ritonga (2005) hasil penelitian laboratorium menunjukkan komposisi plak terdiri atas $80 \%$ air dan menunjukkan $20 \%$ bahan padat. Komposisi bahan padat plak terdiri atas mikroorganisme, bahan organic (karbohidrat, protein dan lemak) dan bahan anorganik.

Hasil penelitian pada tabel IV menunjukkan rata-rata skor indeks plak pada pemeriksaan dengan Disclosing solution sebesar 3,08, dan rata-rata skor indeks plak pada pemeriksaan dengan kesumba sebesar 2.17 dengan selisih 0,9 I. Hasil uji statistik diperoleh nilai $\rho$-value : $0,000<\alpha(0,05)$ sehingga, dapat disimpulkan terdapat perbedaan indeks plak pada pemeriksaan dengan disclosing solution dan pemeriksaan dengan kesumba. Sejalan dengan hasil penelitian Oktaviani \& Haryani (20I5) yang menyimpulkan terdapat perbedaan yang bermakna antara skor plak pada pengolesan ekstrak buah bit dan disclosing solution. Penelitian ini dan penelitian terdahulu sama-sama mencoba menguji efektifitas bahan alami dibandingkan dengan produk jadi yaitu disclosing solution.

Hasil penelitin menunjukkan bahan kesumba memiliki rata-rata skor yang lebih rendah dibanding disclosing solution. hal tersebut kemungkinan berkaitan dengan kemampuan daya tahan perlekatan bahan. Bahan kesumba sebagai bahan pemeriksaan dibuat dengan cara serbuknya diencerkan dengan air, sifat fisik bahan ini tidak dapat bertahan lama dan sebagian mudah terhapus ketika terbilas oleh saliva atau aktivitas berkumur dengan air yang merupakan bagian dari tahapan pemeriksaan, sehingga setelah berkumur sebagian pewarnaan plak akan memudar.

Bahan disclosing solution memang diproduksi secara khusus untuk berfungsi sebagai pewarna plak dalam tindakan medis perawatan gigi dan mulut. Menurut Chowdary (dalam Mangiri et al, 2018) disclosing solution digunakan untuk memvisualisasikan dan mengidentifikasi plak gigi pada permukaan gigi, sehingga sangat berguna untuk melihat plak bakteri yang transparan untuk keperluan instruksi kebersihan mulut, evaluasi dan penelitian.

Bahan disclosing akan mampu mempertahankan pewarnaan plak meskipun ada aktivitas berkumur setelah aplikasi bahan, menurut Putri \& Herijulianti (2013) disclosing kadang tidak disukai karena rasa tidak enak, disclosing mempunyai kemampuan dapat mewarnai mukosa selama beberapa jam.

Perbedaan hasil tersebut, menunjukkan efektifitas bahan disclosing lebih akurat dalam memberikan gambaran hasil pemeriksaan plak. Menurut Oktaviani \& Haryani (2015) menyatakan semakin banyak skor plak yang didapatkan, larutan pewarna tersebut semakin baik dalam mewarnai dan menempel pada permukaan plak karena dapat menunjukan lokasi dan pewarnaan plak. Semakin sedikit skor plak yang didapatkan, larutan atau bahan pewarna tersebut kurang baik menempel pada permukaan plak.

\section{KESIMPULAN}

Berdasarkan hasil penelitian dan pembahasan dapat ditarik kesimpulan bahwa terdapat perbedaan indeks plak pada pemeriksaan dengan disclosing solution dan pemeriksaan dengan kesumba dengan nilai $\rho$-value : $0,000<\alpha(0,05)$,

Saran penelitian ini adalah praktisi kesehatan gigi sebaiknya menggunakan disclosing solution sebagai bahan utama dalam prosedur pemeriksaan plak karena hasil yang lebih akurat, tetapi sebagai alternative jika bahan tersebut tidak tersedia maka dapat menggunakan bahan kesumba. Untuk pengembangan riset yang lebih 
mendalam sangat dianjurkan untuk dilakukan penelitian lanjutan dengan mengoptimalkan formulasi bahan alami kesumba tersebut sehingga dapat meningkatkan efektifitas fungsi pemeriksaan plaknya.

\section{REFERENSI}

I. RI, K. (20I3). Riset Kesehatan Dasar (Riskesdas) tahun 2013. Jakarta: Kementerian Kesehatan RI.

2. Newman, Michael G; Takei, Henry H; Carranza, F. A. (2002). Carranza's Clinical Periodontology 9th Ed. In Carranza's Clinical Periodontology. https://doi.org/ I0.1017/CBO978I I074I5324.004

3. Fatmasari, D., Musthofa, S., \& Santoso, B. (20I4). Efektifitas Buah Bit (Beta Vulgaris) Sebagai Disclosing Solution (Bahan Identifikasi Plak). ODONTO: Dental Journal, I(2), 6. https://doi.org/I0.30659/odj.I.2.6-9

4. Oktaviani N, Haryani W, S. (20I5). Perbedaan pengolesan ekstrak buah bit dan disclosing solution terhadap skor plak pada siswa SDN Kradenan 3 Magelang. Jurnal Gigi Dan Mulut, 2, 19-22.

5. Fatimatuzzahro, N., Prasetya, R. C., \& Amilia, W. (2016). Gambaran Perilaku Kesehatan Gigi Anak Sekolah Dasar di Desa Bangalsari Kabupaten Bantaeng. Jurnal IKESMA, I2(2), 85.

6. Suparmi, Israhnanto Isradji, dan D., \& Fatmawati. (20II). Kadar SGOT dan SGPT Setelah Pemberian Serbuk Pewarna dari Pigmen Selaput Biji Kesumba Keling (Bixa orellana). Penelitian Studi Eksperimental Pada Mencit Putih Galur Balb/C.

7. Ritonga. (2005). Plak Gigi. Medan: Universitas Sumatera Utara.

8. Mangiri, B. S., Yani, S., \& Anitasari, S. (2018). Sari Buah Naga Super merah (Hylocereus costaricensis) Sebagai Pewarna Alami Plak Gigi. Jurnal Material Kedokteran Gigi, $\quad 7(\mathrm{I}), \quad 28$. https://doi.org/l0.32793/jmkg.v7il.278

9. Putri MH, Herijulianti E, N. N. (20/3). Ilmu Pencegahan Penyakit Jaringan Keras dan Jaringan Pendukung Gigi. Jakarta: EGC. 